\title{
FORECASTING STEEL DEMAND IN CHINA
}

by

Dongling Chen Kenneth W. Clements

E. John Roberts

E. Juery Weber

DISCUSSION PAPER 90.24 NOVEMBER 1990

ISBN 0-86422-695-0 
November 1990

\title{
FORECASTING STCEL DEMAND IN CIIINA*
}

\author{
by \\ Dongling Chen \\ Kenneth W. Clements \\ E. John Roberts \\ L. Juerg Weber \\ Economic Research Centre \\ Department of Economics \\ The University of Western Australia
}

* The third author is employed by the WA Department of Resources Development. The first author wishes to acknowledge the generous financial support of AIDAB. We would like to acknowledge the assistance of Louisa Towie and the comments of Meher Manzur. 


\section{CONTENTS}

1. Introduction

2. The World Iron and Steel Industries

3. A Review of Previous Approaches

4. The Database

5. Vector Autoregressions

6. Estimates of the Model

7. The Forecasts

8. Concluding Comments

Appendix 1: The Data Source

Appendix 2: Technical Details of the Model

References 


\section{LIST OF TABLES}

1. Steel intensity

2. World steel production

3. Crude steel production by process

4. The Chinese data

5. Log-changes of the data

6. Average annual log-changes

7. Correlation coefficients

8. Variance decomposition

9. The forecasts

LIST OF FIGURES

1. Steel demand in China

2. Previous forecasts of steel consumption

3. Time-series plots of the data.

4. Scatter plots of steel demand against other variables

5. Autocorrelations of steel demand

6. The impulse response functions

7. Responses of steel to five shocks

8. Actual and forecast values, changes

9. Actual and forecast values, levels 


\section{Introduction}

Stecl demand in China has increased from about 1 million tons p.a. in the early 1950s to almost 60 million in the late 80s. This rapid growth, which has averaged about 10 percent p.a., has by no means been smooth. For example, during the "Three-Year Natural Disaster" period in 1960-62 steel consumption fell from 11 to 5 million tons. Figure 1 shows the evolution of steel demand from 1952 to 1988.

The objective of this paper is to develop forecasts of steel dentand in China to the year 2000. In Section 2 of the paper we review recent

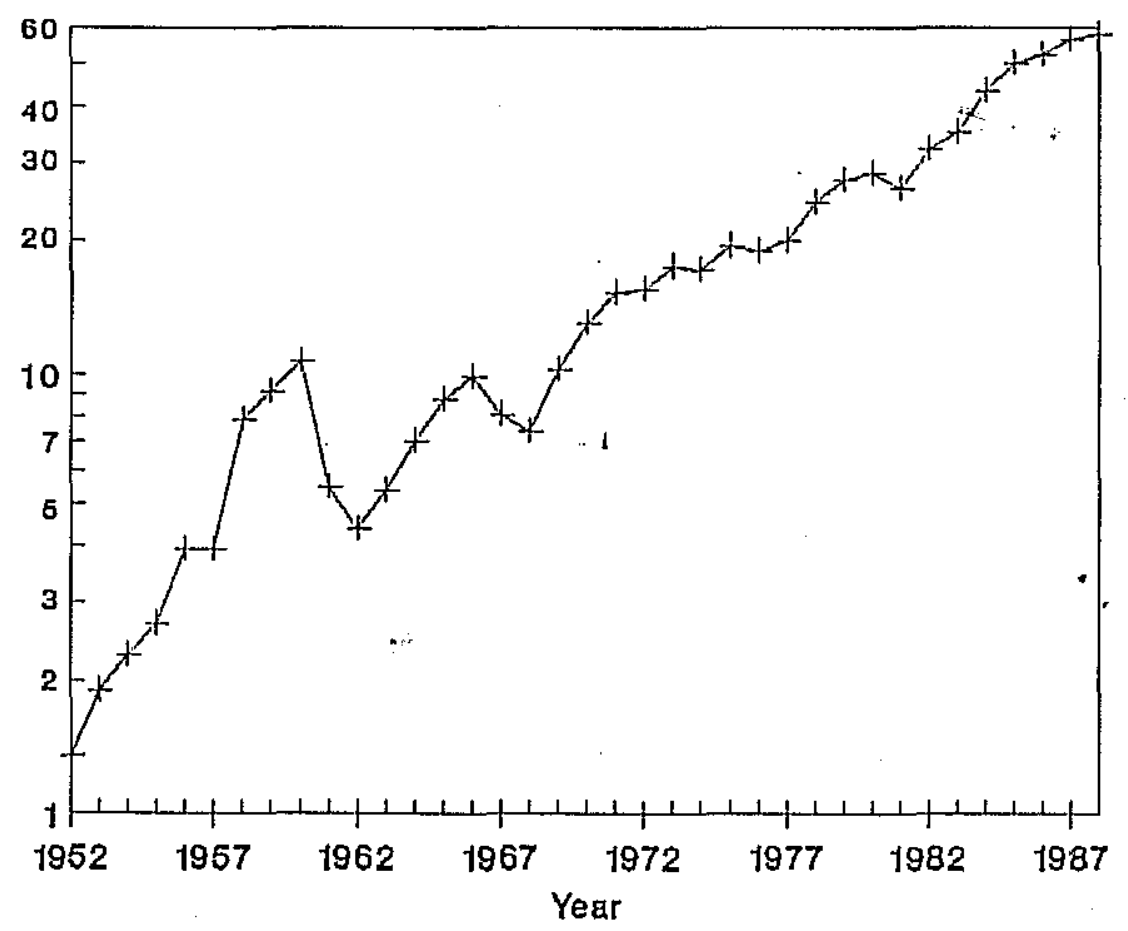

Fig. 1 -- Steel demand in China (million tons) 
developments in the world iron and steel markets. Section 3 surveys the previous literature on this topic. Our conclusions from this section are that (i) there seems to be no real consensus on how best to forecast steel; and (ii) previous applications to the Chinese case leave considerable room for improvement. Section 4 presents the Chinese data as well as a preliminary analysis of steel demand. In Section 5 we discuss the forecasting methodology to be used, viz. vector autoregressions. Sections 6 and 7 deal with estimates of the model and the actual forecasts, while Section 8 presents concluding comments.

2. The World Iron and Steel Industries

In 1989 world steel consumption amounted to 782 mt. The main consümers were the USSR (157 mt), the USA (104 mt), Japan (94 mt) and China (63 mit). -

The world steel market can be usefully split into developed and developing countries. In developed countries, demand is sluggish as it is dependent upon modernising existing infrastructure and replacement demand for consumer durable goods. In addition, technical change and material substitution serve to pull down the demand for steel in developed countries.

By contrast, steel consumption in developing economies is expanding. Between 1970 and 1985, steel demand increased at an average annual rate of 6.4 percent. This buoyancy is due to growth in the provision of infrastructure and increasing demand for consumer durables. Table 1 illustrates this contrast between developed and developing countries.

The western industrial countries, the traditional steel-producing nations, have recently experienced excess capacity as a result of low domestic demand. The newly industrialised countries, as part of their industrial 
developments in the world iron and steel markets. Section 3 surveys the previous literature on this topic. Our conclusions from this section are that (i) there seems to be no real consensus on how best to forecast steel; and (ii) previous applications to the Chinese case leave considerable room for improvement. Section 4 presents the Chinese data as well as a preliminary analysis of steel demand. In Section 5 we discuss the forecasting methodology to be used, viz. vector autoregressions. Sections 6 and 7 deal with estimates of the model and the actual forecasts, while Section 8 presents concluding comments.

\section{The World Iron and Steel Industries}

In 1989 world steel consumption amounted to 782 mt. The main consumers : were the USSR (157 mt), the USA (104 mt), Japan (94 mt) and China (63 mt). "

The world steel market can be usefully split into developed and developing countries. In developed countries, demand is sluggish as it is dependent upon modernising existing infrastructure and replacement demand for consumer durable goods. In addition, technical change and material substitution serve to pull down the demand for steel in developed countries.

By contrast, steel consumption in developing economies is expanding. Between 1970 and 1985, steel demand increased at an average annual rate of 6.4 . percent. This buoyancy is due to growth in the provision of infrastructure and increasing demand for consumer durables. Table 1 illustrates this contrast between developed and developing countries.

The western industrial countries, the traditional steel-producing nations, have recently experienced excess capacity as a result of low domestic demand. The newly industrialised countries, as part of their industrial 
Table 1

Steel intensity

\begin{tabular}{lccc}
\hline Country/region & $1970 \quad 1985$ & $\begin{array}{c}\text { Percentage } \\
\text { change } \\
1970-85\end{array}$ \\
\hline
\end{tabular}

Developed countries

\begin{tabular}{|c|c|c|c|}
\hline USA & 93 & 51 & -45 \\
\hline Canada & 187 & 67 & -23 \\
\hline Japan & 180 & 92 & -49 \\
\hline UK & 114 & 52 & -54 \\
\hline W. Germany & 107 & 58 & -46 \\
\hline Italy & 122 & 86 & -30 \\
\hline France & 83 & 36 & -57 \\
\hline \multicolumn{4}{|c|}{ Developing countries } \\
\hline Brazil & 93 & 65 & -30 \\
\hline Mexico & 69 & 53 & -23 \\
\hline Middle East & 49 & .67 & 37 \\
\hline India & 94. & 108 & 15 \\
\hline South Korea & 54 & 107 & 98 \\
\hline Taiwan & 108 & 180 & 67 \\
\hline 0ther Asia & 108 & 138 & 28 \\
\hline
\end{tabular}


expansion, have brought on-streall considerable new steel-making capacity. Table 2 illustrates the decline in steel production by the industrial countries and the major expansion in the newly industrialised countries.

Production technology has adapted to the contraction of steel demand in industrialised countries. In the USA in particular minimills (small steel plants) have grown significantly. These use electric arc furnace technology fueled by either scrap metal or reduced iron, whereas the conventional basic oxygen furnace requires pig iron or reduced iron. The minimill technology creates a small range of specialised products for specific markets. Table 3 shows that with the exception of Brazil, during the 1980s the electric arc furnace has increased its share of steel production. In most cases there hás been a minor decrease in the use of basic oxygen furnace technology; and the older open hearth furnace technology has been almost totally replaced.

Other technological advances in steel production concern casting, roliing and smelting. Continuous casting has improved yields and reduced reheating costs. Future developments may allow the casting of slabs and blooms with near-finished shapes to simplify rolling. Rolling technology is also improving with computer control of thickness tolerance, the development of thermo-mechanical processes to improve material properties and single proeess of rolling/picking/annealing. In the area of hot metal production, the direct smelting of iron ore to prodüce a virgin metal may see the end of the use of small blast furnaces. In addition, high-grade steel products are being improved with the development of micro-alloys and heat-treatment processes. 
T'able 2

World steel production

\begin{tabular}{lrrr}
\hline Country/region & 1979 & 1988 & $\begin{array}{c}\text { Percentage } \\
\text { change } \\
1979-88\end{array}$ \\
\hline USSR & 149 & 163 & 9 \\
European Community & 154 & 138 & -10 \\
Japan & 112 & 106 & -5 \\
USA & 124 & 91 & -27 \\
China & 34 & 59 & 74 \\
Brazil & 14 & 19 & 36 \\
S.Korea & 8 & 22 & 175 \\
\hline
\end{tabular}

Steel production is in millions of tons of crude steel.

Table 3

Crude steel production by process

(Percentage share)

\begin{tabular}{|c|c|c|c|c|c|c|}
\hline \multirow{2}{*}{ Country/region } & \multicolumn{3}{|c|}{1982} & \multicolumn{3}{|c|}{1989} \\
\hline & $\begin{array}{l}\text { Basic } \\
\text { oxygen } \\
\text { furnace }\end{array}$ & $\begin{array}{l}\text { Electric } \\
\text { arc } \\
\text { furnace }\end{array}$ & $\begin{array}{l}\text { Open } \\
\text { hearth } \\
\text { furnace }\end{array}$ & $\begin{array}{l}\text { Basic } \\
\text { oxygen } \\
\text { furnace }\end{array}$ & $\begin{array}{l}\text { Electric } \\
\text { arc } \\
\text { furnace }\end{array}$ & $\begin{array}{l}\text { Open } \\
\text { heartli } \\
\text { furnace }\end{array}$ \\
\hline \multicolumn{7}{|l|}{ Buropean } \\
\hline Community & 74 & 26 & 1 & 70 & 30 & 0 \\
\hline Japan & 73 & 27 & 0 & 69 & 31 & 0 \\
\hline USA & 61 & 31 & 8 & 60 & 36 & 5 \\
\hline Brazil & 66 & 27 & 7 & 75 & 23 & 3 \\
\hline S.Korea & 75 & 25 & 0 & 71 & 30 & 0 \\
\hline
\end{tabular}




\section{3. $\Lambda$ Review of Previous Approaches}

Approaches to forecasting metals demand can be broadly classified into econometric and intensity-of-use approaches.

\section{Econometric Approaches}

The most common method of analysing the demand for a metal has been to estimate econometrically a demand function. Since steel, like most metals, is used predominantly as an input into production, its demand is a derived demand, being determined ultimately by the demand for finished products. As such, the demand for steel depends on the real prices of steel, substitutes: and complements and consumer demand for output. Technical progress, and institutional and political constraints may also influence the quantity of steel consumed (Wagenhals, 1984).

Most forecasts of steel demand are derived using some form of mineral model. Such a model provides a formal representation of a mineral market, industry or system where the behavioural relationships reflect the underlying economic and engineering factors as well as the political and social institutions. Mineral models have been broadly categorised into three types: econometric models, engineering models and input/out models (Labys et al., 1985). They are often linked with larger macroeconomic models and, in many cases, are proprietary and the details are not disclosed. Numerous models can be found in the literature; for example, Wagenhals (1983) lists almost 200 econometric non-ferrous metals markets models.

Both the single-equation and the mineral model approaches are considered 
by Tilton (1989b) to suffer from shortcomings, particularly in their ability to analyse long-run trends in demand where new technology may be important in driving both resource-saving imnovations and material substitution. For this reason he advocates the intensity-of-use approach.

\section{The Intensity- of-Use Approach}

Intensity of use is the amount of metal consumed per unit of GDP (Tilton, 1986). In this method, metal consumption is calculated using exogenous projections of GDP and population and an "intensity-of-use" table. This method came into prominence in the early 1970s with the publication of Nalenbaum's (1973) projections of mineral demand.

A key tenet of the approach is a behavioural assumption that intensity of use and per capita income typically have an inverted U-shaped relationship : (Malenbaum, 1975). The rationale underlying the assumption is that the mix of" goods and services produced in the economy (later to be defined as the production composition of income), and hence the intensity of, metal use, changes with economic development. As the economy evolves, there is a shift towards less material-intensive sectors such as services, resulting in a decline in the intensity of metal use (Tilton, 1989a).

The abrupt downward shift in the long-run growth trends for most metals around 1973/74 led to further development of the intensity-of-use approach. Tilton (1986) proposed that intensity of use depended on two factors: the product composition of income (PCI); and the market composition of products (MCP), which reflects the materials required to produce these goods and services. Tilton and others (Canavan, 1983, and Roberts, 1985) have suggested that changes in the NCP due to a shift towards a more materials-intensive 
durable goods sector have offset the changes in PCI. As a consequence, they have argued that intensity of use need not follow the inverted U-shaped relationship. Tilton (1989a) cautions, however, that the debate over the relative importance of PCI and MCP has yet to be resolved.

There are only a few published examples of the use of the "Tilton style" intensity-of-use approach (see, for example, Canavan, 1983, Castro, 1988, and Roberts, 1985). Roberts' (1990) study of the US steel industry represents an important extension of the technique by adding exports and providing a detailed analysis of the estimation of MCP and PCI.

\section{China}

Several different approaches have been used to forecast steel consuliption in China. Findlay and Xin (1985) derived forecasts of the demand for finjishéd steel in China for the period 1985-2000 using a demand equation relating steet consumption to GDP, population and exports. The equation was estimated using , data from eight Asian countries over the period 1966-1984. Two dummy variables were included to pick up the influence of the stage of development on steel demand. The export variable was not significant and dropped from the equation. The forecast demand for steel for the year 2000 ranged from 66 million tons for an annual growth rate in national income of 5 percent to 80 mt for a 7 percent growth rate.

Zhang Xiao-qin (1988) estimated a demand function which related apparent steel consumption to industrial production, exports, the price of steel, population and two dumny variables to pick up (i) consumption booms in the years 1960, 1978 and 1979 and (ii) slumps in 1981 and 1982. The data were for the period 1949-1986. The forecast of steel consumption for the year 2000 
based on these estimates, assuming an annual growth rate in industrial production of 7.2 percent, was about 200 int.

Yong Gan Shen (1988) presents a range of forecasts based on the relationship between steel consumption and GDP for the period 1969-1986. A regression of total steel demand on national income yielded predicted steel demand of between 126 and 147 mt for the year 2000 . When the analysis was carried out on a per capita basis, the result was between 130 and 151 mit. Yong Gan Shen also experimented with two measures of intensity of use: (i) steel consumption divided by gross value of output of industry and agriculture and (ii) steel consunption divided by national income. Relating these to national income resulted in forecasts ranging from 128 to 150 mt.

Pigure 2 illustrates the above forecasts for the year 2000. llere, the, forecasts of $73 \mathrm{mt}$ for Findlay and $X \mathrm{in}$ and 137 for Shen are the approximate mid-points of the ranges reported above.

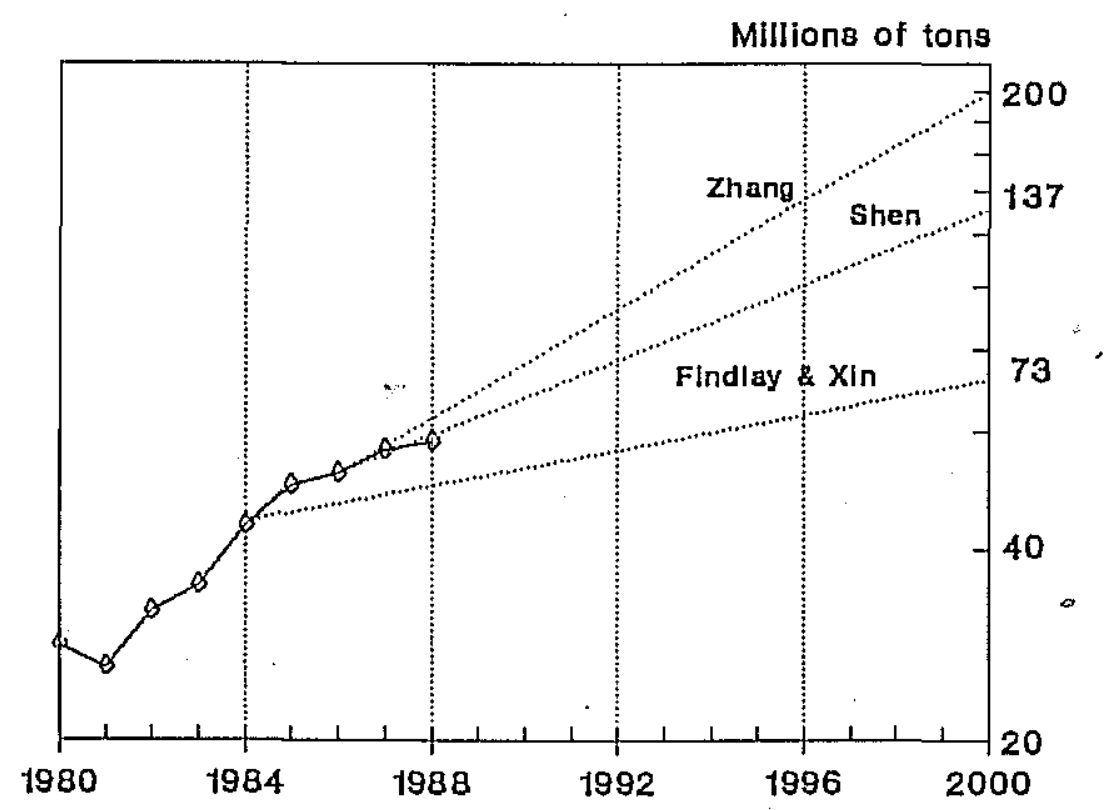

Fig. 2 -- Previous forecasts of steel consumption 


\section{The Database}

The data to be used consist of Chinese real national income, the consumer price index, noney supply; real investment and steel consumption, all from the Statistical Year Book of China, 1985 and 1989. Appendix 1 gives full details of the data.

Table 4 lists the raw data and Table 5 and Figure 3 present them in log-change form. (Log-changes, when multiplied by 100, are approximately percentage changes.) As can be seen from the upper part of the figure, there were major recessions in 1960-62, the "Three-Year Natural Disaster" period, and in 1967-1968, the beginning of the Cultural Revolution. Also, investment is more volatile than income, as is to be expected. The middle part of the figure reveals that the rate of monetary expansion is quite variable, muchl : more so than inflation. The bottom part shows that steel demand is subject. to large swings, ranging from growth of 69 percent in 1958 to 67 percent contraction in 1961.

Table 6 gives the average annual growth rates of the five variables for each decade. In the 1980s real income grew on average by 8 percent per anmum, investment by 9 percent and steel consumption by 8 percent. Table 7 shows that steel is closely correlated with income and investment and to a lesser extent with money. To explore further the relationships between steel and the other variables, we present four scatter plots in Figure 4. Here, the solid lines are the least-squares regression lines. These show that, as a first approximation, income and investment are major determinants of steel demand. Income by itself explains, 77 percent of the variation in steel demand, while investment accounts for 88 percent. The income elasticity of steel is 1.8 (standard error $=.2$ ) and the investment elasticity is .6 (.04). 
T'able 4

The Chinese data

\begin{tabular}{|c|c|c|c|c|c|}
\hline Year & Income & Prices & Money & Investment & Steel \\
\hline 1952 & 626.75 & 93.98 & 8.60 & 46.35 & 1.35 \\
\hline 1953 & 757.47 & 93.60 & 12.30 & 97.85 & 1.90 \\
\hline 1954 & 772.86 & 96.78 & 15.90 & 106.09 & 2.27 \\
\hline 1955 & 795.88 & 99.01 & 19.90 & 106.29 & 2.67 \\
\hline 1956 & 882.00 & 100.00 & 26.70 & 160.84 & 3.95 \\
\hline 1957 & 894.58 & 101.50 & 35.20 & 149.00 & 3.95 \\
\hline 1958 & 1099.28 & 101.70 & 55.20 & 274.39 & 7.86 \\
\hline 1959 & 1190.82 & 102.62 & 68.30 & 358.63 & 9.14 \\
\hline 1960 & 1153.12 & 105.80 & 66.30 & 393.74 & 10.70 \\
\hline 1961 & 810.16 & 122.94 & 55.40 & 126.94 & 5.49 \\
\hline 1.962 & 724.08 & 127.61 & 41.10 & 68.40 & 4.39 \\
\hline 1963 & 832.77 & 120.08 & 45.70 & 97.15 & 5.38 \\
\hline 1964 & 1008.31 & 115.64 & 55.50 & 143.46 & 6.98 \\
\hline 1965 & 1232.71 & 112.52 & 65.20 & 192.77 & 8.72 \\
\hline 1966 & 1413.81 & 112.18 & 72.30 & 227.14 & 9.88 \\
\hline 1967 & 1334.91 & 111.39 & 73.90 & 168.52 & 8.07 \\
\hline 1968 & 1269.00 & 111.50 & 78.30 & 135.93 & 7.38 \\
\hline 1969 & 1466.29 & 110.28 & 75.90 & 223.91 & 10.25 \\
\hline 1970 & 1749.99 & 110.06 & 79.50 & 334.44 & 13.16 \\
\hline 1971 & 1900.49 & 109.29 & 90.30 & 381.85 & 15.39 \\
\hline 1972 & 1958.40 & 109.07 & 105.20 & 378.49 & 15.61 \\
\hline 1973 & 2112.59 & 109.72 & 121.20 & 399.30 & 17.65 \\
\hline 1974 & 2129.28 & 110.27 & 136.50 & 420.04 & 17.26 \\
\hline 1975 & 2265.31 & 110.49 & 149.60 & 493.19 & 19.60 \\
\hline 1976 & 2189.96 & 110.82 & 159.10 & 4.72 .77 & 19.02 \\
\hline 1977 & 2338.99 & 113.04 & 181.60 & 485.05 & 20.13 \\
\hline 1978 & 2644.25 & 113.83 & 210.60 & 587.46 & 24.4 .6 \\
\hline 1979 & 2885.24 & 116.11 & 281.00 & 602.33 & 27.37 \\
\hline 1980 & 2996.55 & 123.07 & 399.50 & 606.05 & 28.25 \\
\hline 1981 & 3127.07 & 126.03 & 523.70 & 529.65 & 26.09 \\
\hline 1982 & 3315.60 & 128.42 & 675.40 & 658.22 & 31.94 \\
\hline 1983 & 3633.31 & 130.35 & 892.50 & 730.31 & 35.15 \\
\hline 1984 & 4217.93 & 134.00 & 1214.70 & 884.47 & 43.20 \\
\hline 1985 & 4828.82 & 145.79 & 1622.60 & 1152.68 & 49.83 \\
\hline 1986 & 5111.34 & 154.54 & 2237.60 & 1280.26 & 51.93 \\
\hline 1987 & 5645.28 & 165.82 & 3073.30 & 1385.83 & 56.34 \\
\hline 1988 & 5989.92 & 196.50 & 3801.50 & 1380.58 & 58.03 \\
\hline
\end{tabular}

Income and investment are in terms of 1956 prices. Income, investment and the money supply are in 100 million Yuans. Steel production is in millions of tons. 
l'able 5

Log-changes of the data

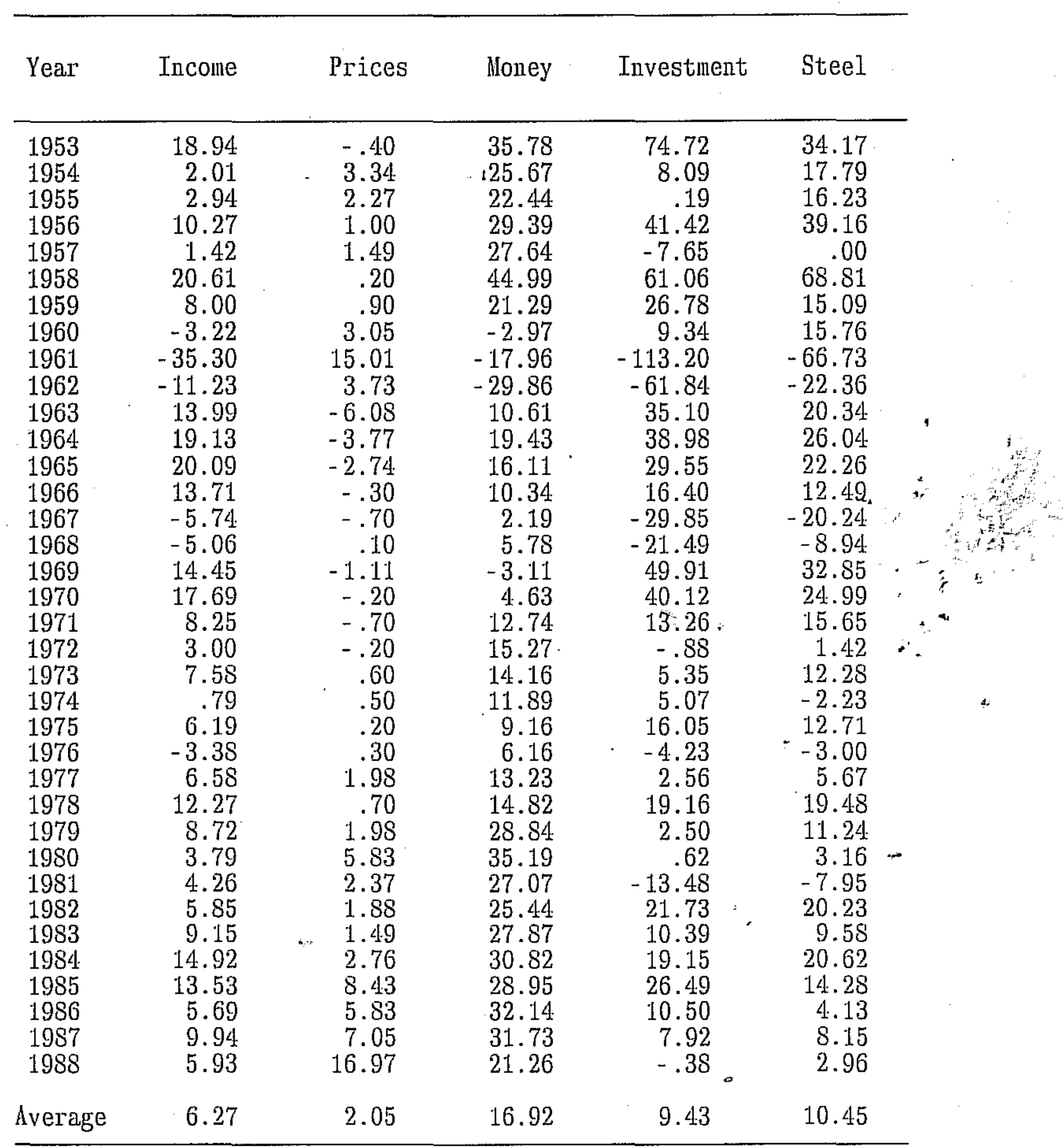

All entries are to be divided by 100 . 

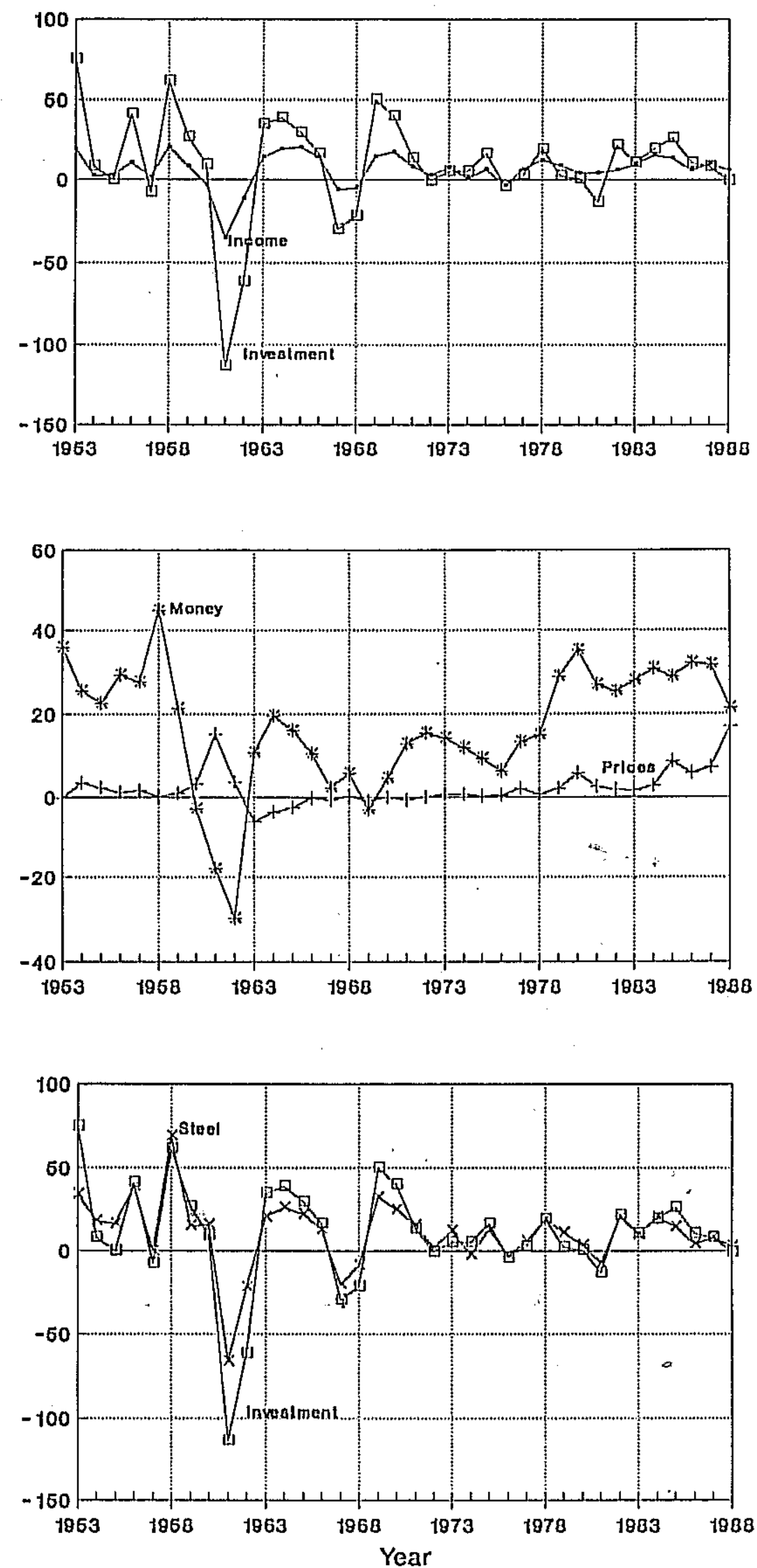

Fig. 3 -- Time-series plots of the data (log-changes $\times 100)$ 
Table 6

Average annual log-changes

(Standard deviations in parentheses)

\begin{tabular}{lcccccc}
\hline Period & Income & \multicolumn{1}{c}{ Prices } & Money & Investment & Steel \\
\hline 1953-59 & $9.17(7.95)$ & $1.26(1.26)$ & $29.60(8.31)$ & $29.23(31.33)$ & $27.32(22.43)$ \\
$1960-69$ & $2.08(17.51)$ & $.72(5.81)$ & $1.06(15.33)$ & $-4.71(51.90)$ & $1.15(30.73)$ \\
$1970-79$ & $6.77(5.86)$ & -.52( & $.88)$ & $13.09(6.61)$ & $9.90(12.98)$ & $9.82(9.26)$ \\
$1980-88$ & $8.12(4.02)$ & $5.85(4.85)$ & $28.94(4.13)$ & $9.22(12.45)$ & $8.35(9.14)$ \\
$1953-88$ & $6.27(10.48)$ & $2.05(4.42)$ & $16.92(15.26)$ & $9.43(32.79)$ & $10.45(21.29)$ \\
\hline
\end{tabular}

All entries are to be divided by 100 .

Table 7

Correlation coefficients

\begin{tabular}{|c|c|c|c|c|c|}
\hline & & Prices & Money & Investment & Steel \\
\hline $\begin{array}{l}\text { Income } \\
\text { Prices } \\
\text { Money } \\
\text { Investment }\end{array}$ & $\cdots$ & -.49 & $\begin{array}{r}.59 \\
-.02\end{array}$ & $\begin{array}{r}.92 \\
-.51 \\
.58\end{array}$ & $\begin{array}{r}.88 \\
-.48 \\
.57 \\
.94\end{array}$ \\
\hline
\end{tabular}

The entries are the correlations between pairs of log-changes of the variables. 

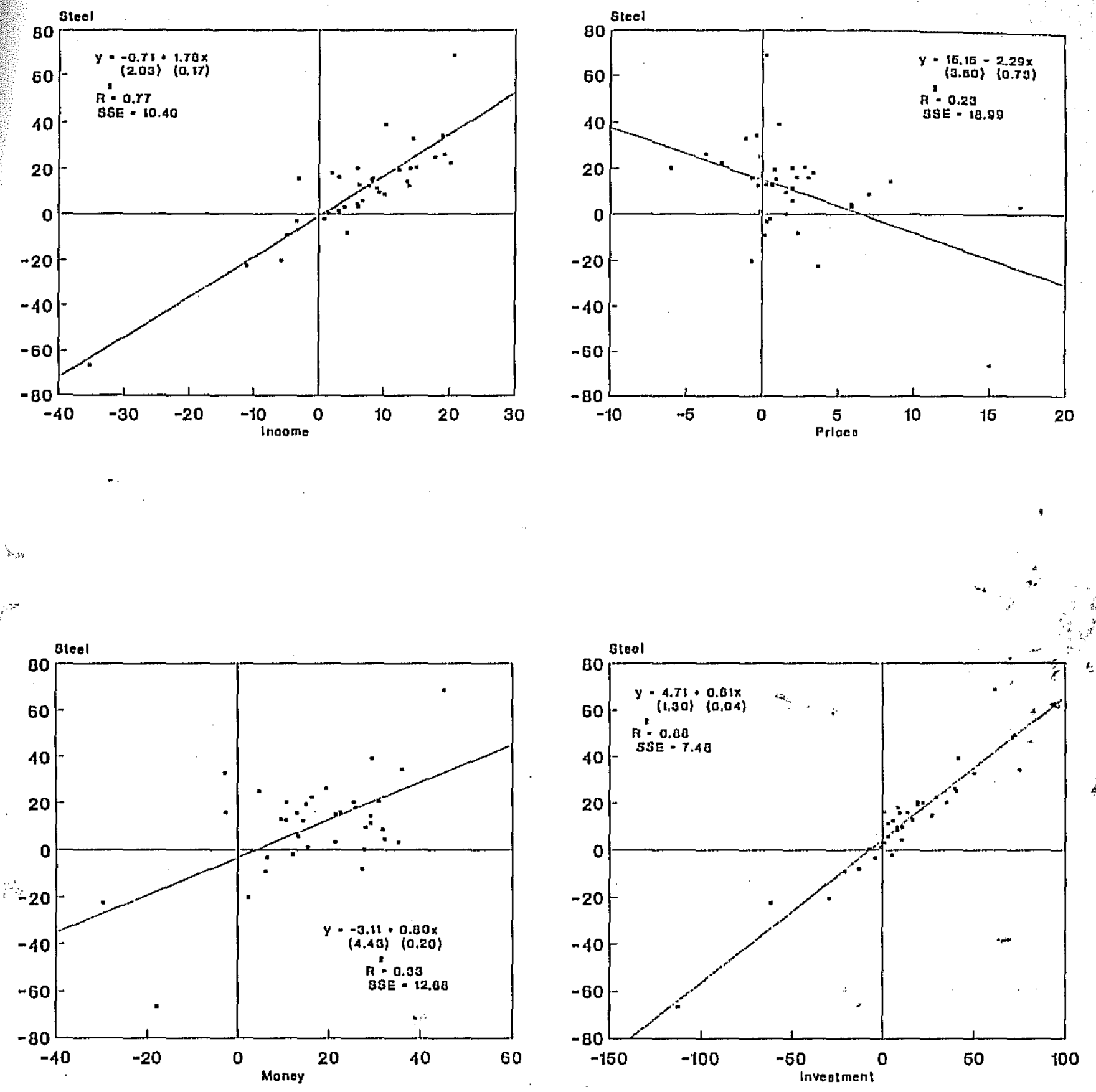

Fig. 4 -- Scatter plots of steel demand against other variables

$(\log$-changes $\times 100)$ 


\section{Vector Autoregressions}

In time-series analysis a macroeconomic variable, such as steel demand in China, is considered to be generated by a stochastic process consisting of an infinite sequence of random variables. If these random variables are correlated, future values of the series can then be forecast. Unlike a structural econometric model, a time-series model is purely statistical, exploiting the serial correlation in a variable. In the 1980s time-series models became important tools in econonic research and forecasting because they provide a low-cost alternative to large-scale structural models and they often outperform the latter.

Recent advances in econometrics have led to multivariate time-series models or vector autoregressions. These models also take account of thé contemporaneous and lagged co-movement between different economic variables:- A VAR model consists of a system of equations in which each variable is regressed on its own lagged values and on the lagged values of all the other variables in the model. Figure 5 shows the autocorrelations of the logarithm of steel demand, which provide the basis for forecasts in univariate time series models. In addition, the VAR model in this paper takes account of the strong co-movement between income, investment, money, prices and steel which is apparent in Figure 3.

Although VAR models do not embody economic theory in the way that structural econometric models do, they impose restrictions on the data that are based on economic reasoning. 'The present model uses two types of restrictions that concern the variables in the model and their causal ordering. Steel demand is analyzed within the framework of a standard 
macroeconomic model consisting of national income, the price level and money stock. Two sectoral equations are added to the macroeconomic core of the model to deal with investment and steel. It is then assumed that within a single year causality runs from output to prices - to money - to investment and to steel. The causal interpretation of the contemporaneous influences is a by-product of the ordering of variables in the so-called Choleski factorization of the contemporaneous covariance matrix of residuals, which provides orthogonal residuals. The moving-average representation can be used to compute impulse responses in all variables to independent; shocks in one variable. This requires orthogonal residuals because it would be wrong to assign impulse responses to innovations in a specific variable if innovations"

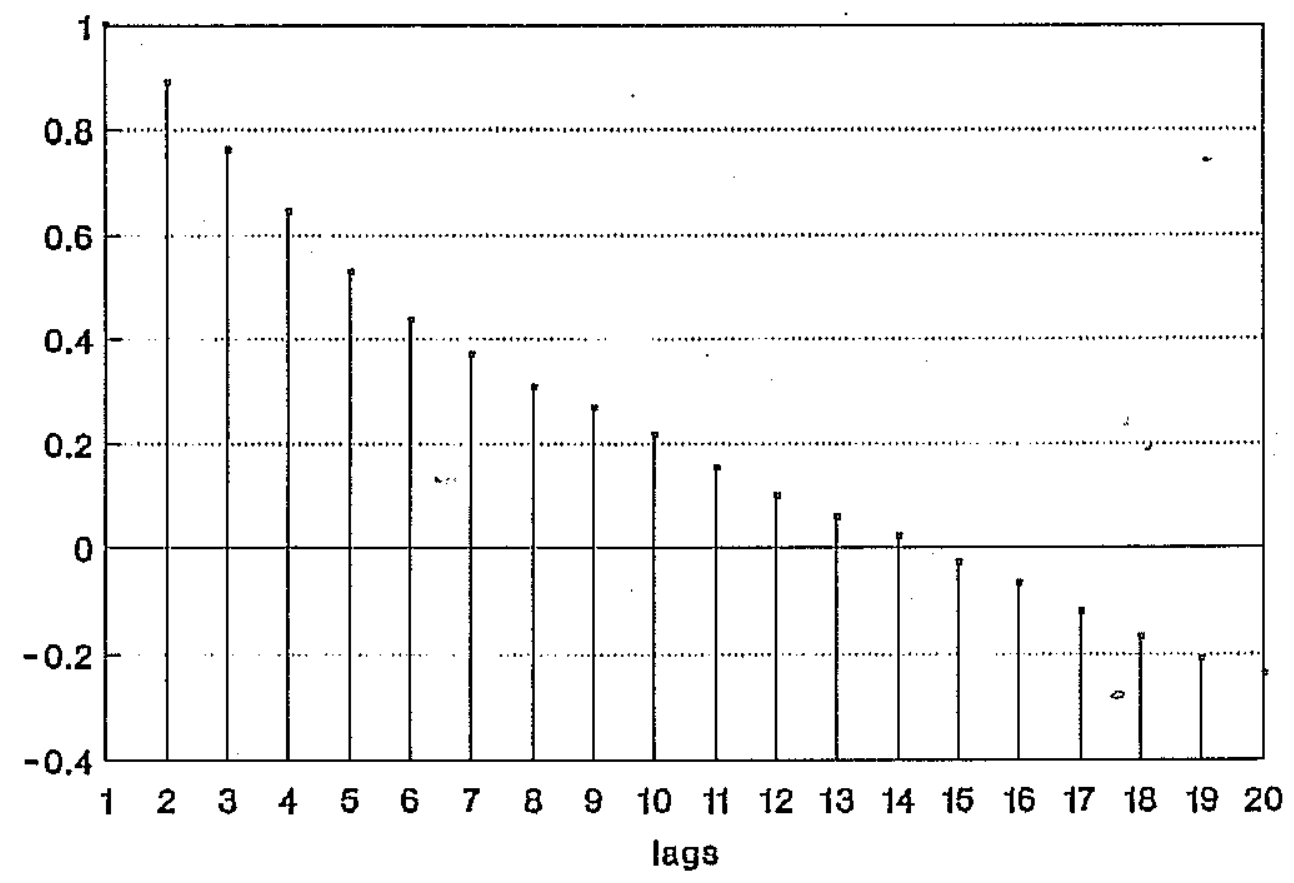

Pig. 5 - Autocorrelations of steel demand 
are correlated across variables.

Vector autoregressions generally suffer from over-parameterization because each variable is regressed on its own lags and on the lags of all other variables. As a consequence, standard errors are large and forecasts uncertain, except in very small models. A model with five variables, four lags and a constant in each equation involves the estimation of 105 regression coefficients. To overcome the degrees-of-freedom problem, Litterman (1979) recommends a Bayesian approach that imposes normal prior distributions on the coefficients with specified means and standard deviations that decline with lag length. In our paper it is assumed that, as a first approximation, all variables follow a random walk process. Therefore, the means of the distributions of the first own lags are set equal to one, and the means of all other lags are zero with geometrically and symmetrically declining standard deviations. See Appendix 2 for details.. 


\section{Estimates of the Model}

The VAR model includes five, variables -- income, prices, money, investment and steel -- all in log-change form. The model was estimated using Theil's (1971 pp. 347-52) mixed estimation technique. The estimates of the coefficients are not shown because they are difficult to interpret. Instead, this section presents the moving average representation of the model which provides decompositions of the forecast errors and impulse responses.

A variable is exogenous if most of the variance of its forecast error is due to its own innovations, rather than to innovations in other variables. Table 8 shows the variance decompositions. Each panel in the table splits the variance of the forecast error in one variable into the innovations in a.l variables. Thus, the figures represent percentage shares that add up to 100 across the colunns.

The table confirms the assumption made earlier that the three" macroeconomic variables - output, prices and money - influence investment and steel demand with no significant reversed causal influence. Only 6 percent of the 4-year-ahead forecast error in steel is accounted for by innovations in steel itself, whereas a total of 78 percent is accounted for by innovations in the three macroeconomic variables. Similarly, 21 percent of the 4-year-ahead forecast error in investment "is due to own innovations and 78 percent due to innovations in the macroeconomic variables. The macroeconomic variables are mostly exogenous, though there is some interdependence among them. For output 74 percent of the 8-year-ahead forecast errors can be assigned to own innovations, for prices 71 percent and for money 70 percent. Prices are exogenous because they are set by the authorities in order to control the economy. The most important supply shocks were the natural disasters in 
l'uble 8

Variance decomposition

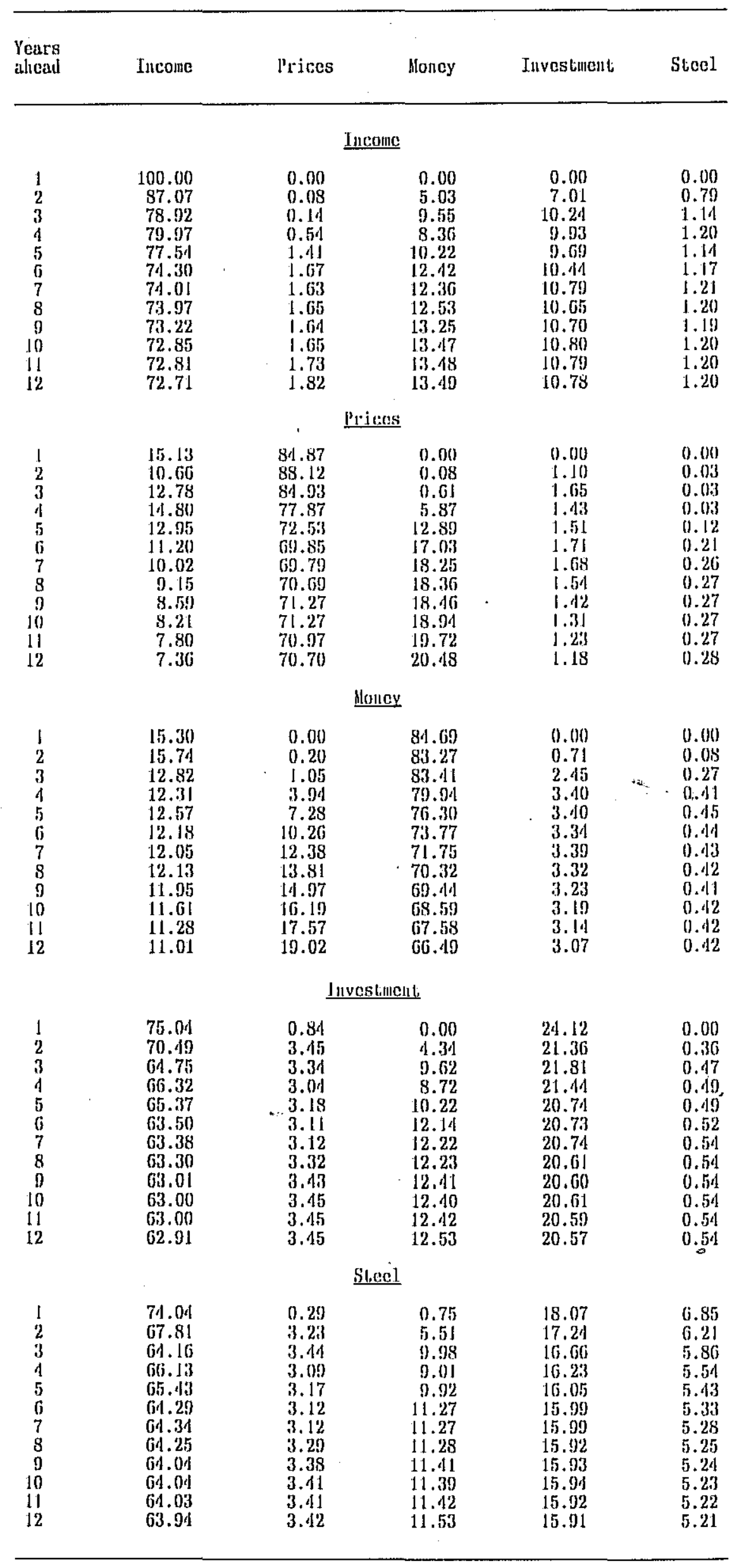


1960-62 and the Cultural Revolution in 1967/68.

The moving-average representation can also be used to calculate impulse responses to an independent shock in one variable. The panels in Figure 6 show the responses to one-standard-deviation shocks, and Figure 7 then summarizes the responses in steel demand. The most significant responses are those to the exogenous variables of the model - output, prices and money. A positive shock to output leads to a strong increase in investment and steel demand for two years. A positive shock to prices induces a strong negative response in investment and steel that lasts for three to four years. Finally, a shock to money induces a rise in steel consumption and investment for 4 years. It should also be noticed that a shock to steel has only a negligible effect on , the other variables, and that a shock to investment only affects steel. Thus. supply and price shocks and monetary disturbances determine investment and steel demand in China. 
Response to a shock in income

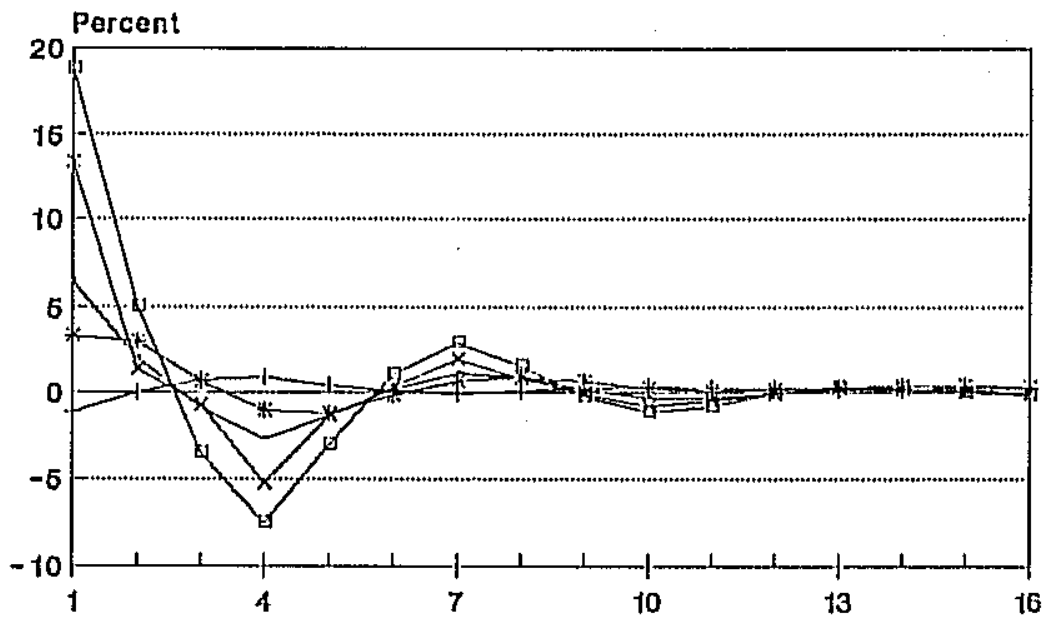

Response to a shock in prices

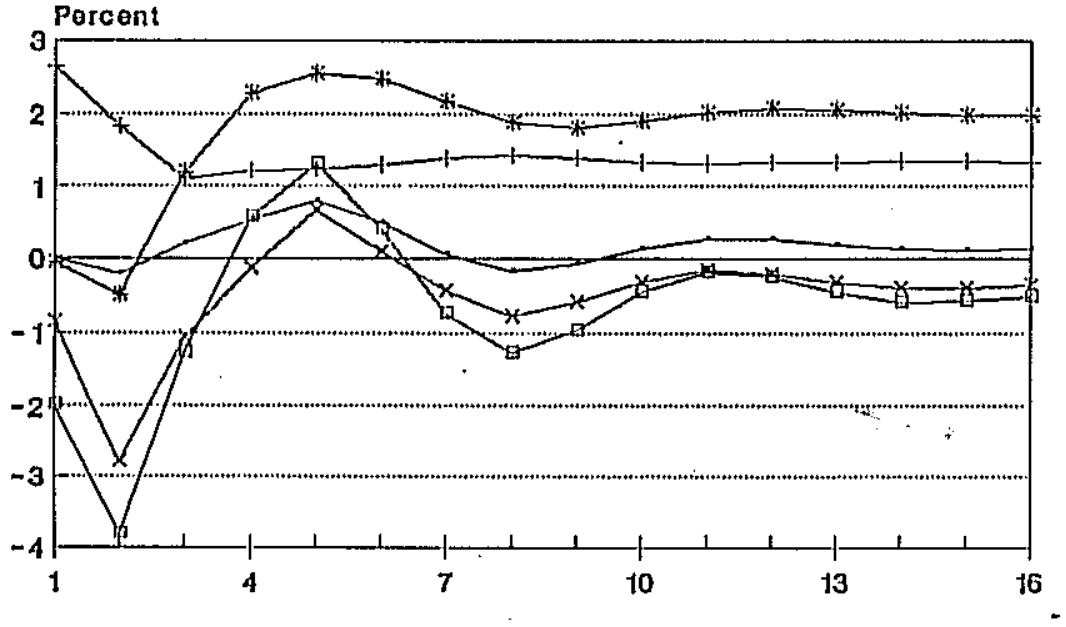

Response to a shock in money

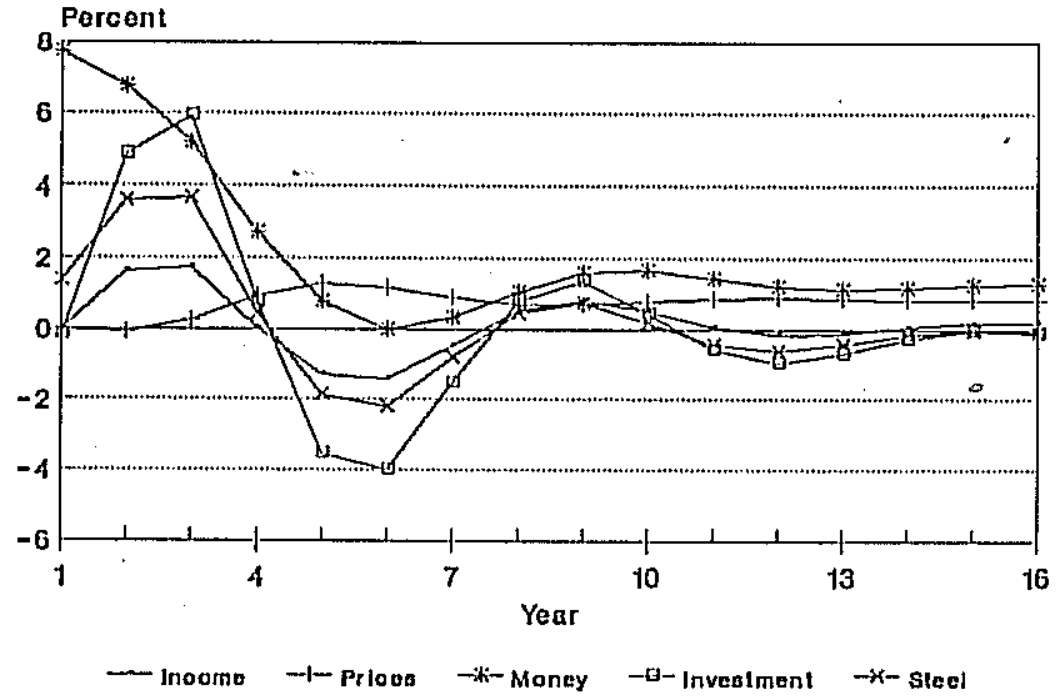

Fig.6 -- The impulse response functions (continued over page) 
Response to a shock in investment

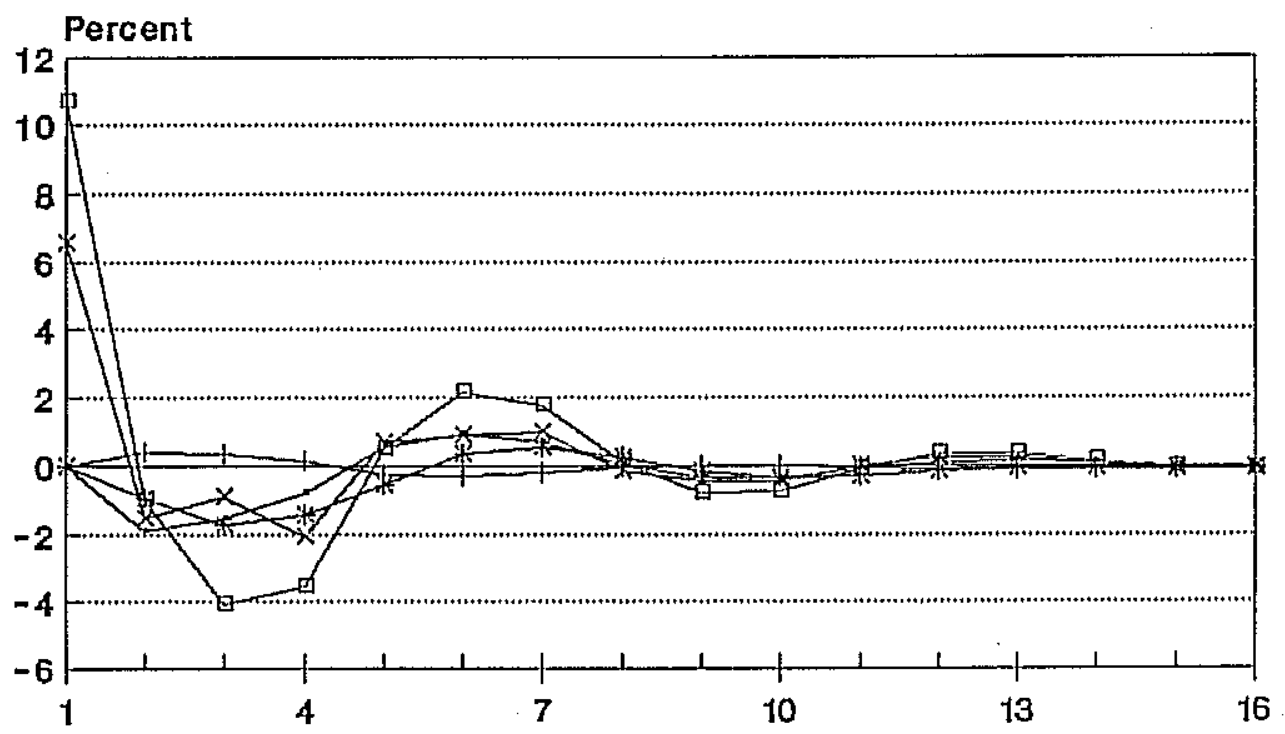

Response to a shock in steel

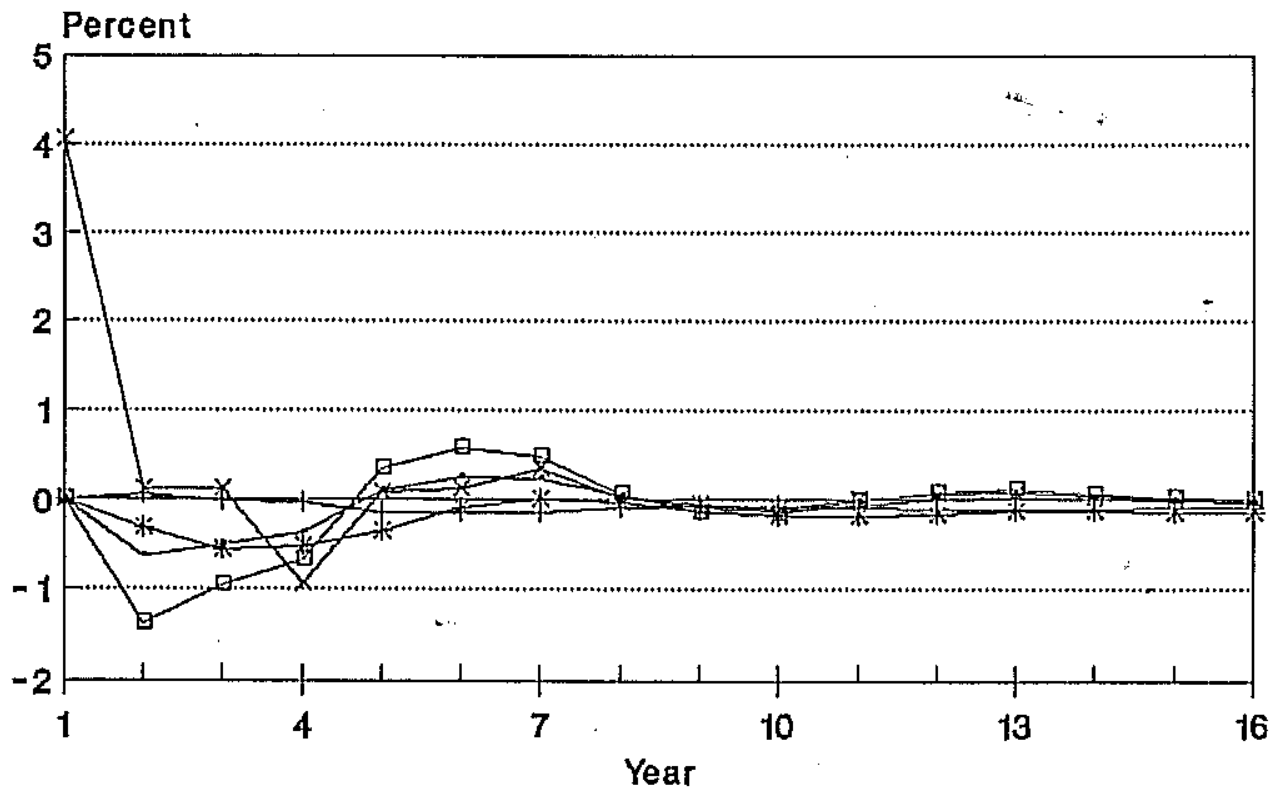

- Income + Prices $\rightarrow$ - Money $\rightarrow$ Investment $\rightarrow$ - sieel

Fig.6 -- The impulse response functions

(continued) 


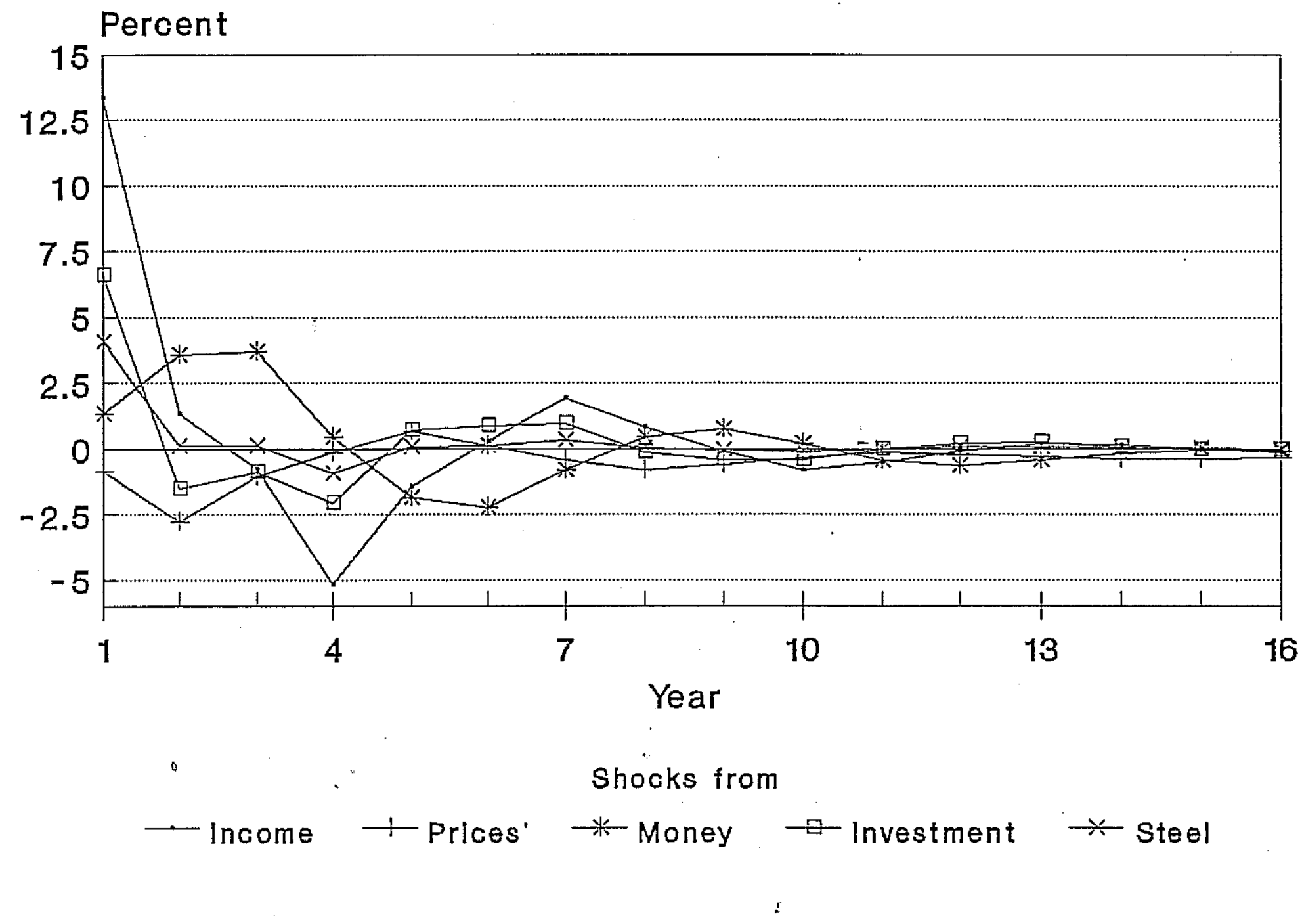

Fig. 7 -- Responses òf, steel to five shocks 


\section{The Forecasts}

We now use the estimated model to forecast steel demand. It should be noticed that as the VAR model is self-contained, there is no need to specify the values of exogenous variables over the forecast period.

Table 9 presents the forecasts and rigures 8 and 9 provide the corresponding graphs. In the forecast for 1989 income increases by 3.3 percent, prices by 14.8 percent and the money supply by 17.9 percent, whereas investment falls by 13.6 percent and steel demand by 5.1 percent. The rates of growth of all macroeconomic variables fall compared to 1988 (see Table 5), and steel demand drops from 58 million tons to 55 million. This reflects the recession in China during the last year. The forecasts of the growth rates for the year 2000 are 8.0 percent for income, 15.0 percent for prices, 34.6 percent for money, 2.5 percent for investment and 5.3 percerit for steel. China * " is currently passing through a recession with low investment and steel demand; steel consumption is predicted to stay below the 1988 level until 1992. Steel demand will then recover and annual rates of growth will reach 10.0 percent in 1992 and 9.2 in 1993. This is the familiar pattern of a strong recovery after a slump. In the second half of the 1990s, the rate of growth in steel demand will approach its long-term value of about 5 percent, which leads to 98 mt being consumed by 2000 . 
Table 9

The forecasts

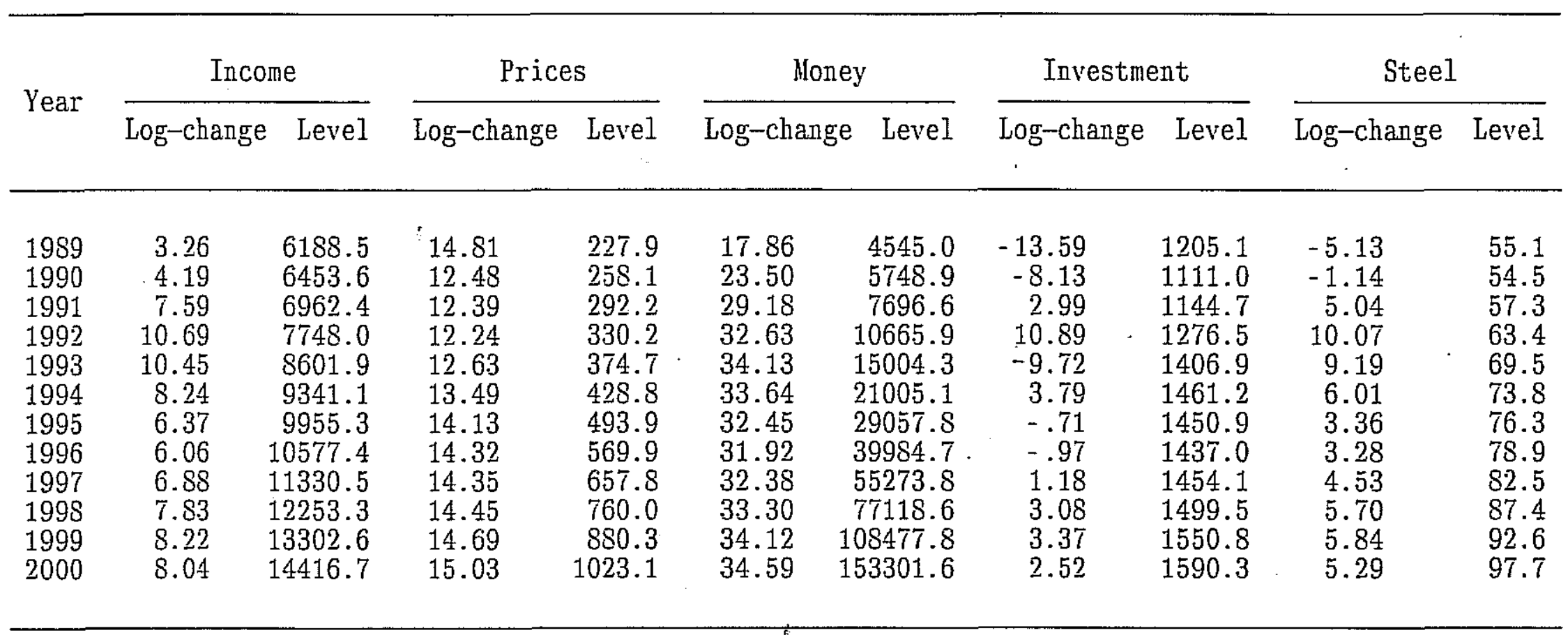

For log-changes, all entries are multiplied by 100 . For levels, income and investment are in terms of 19.56 prices; income, the money supply and investment are in 100 million ruans; and steel demand is in millions of tons.

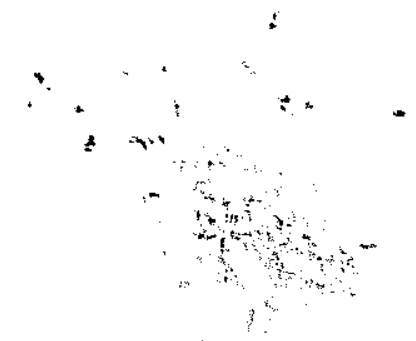



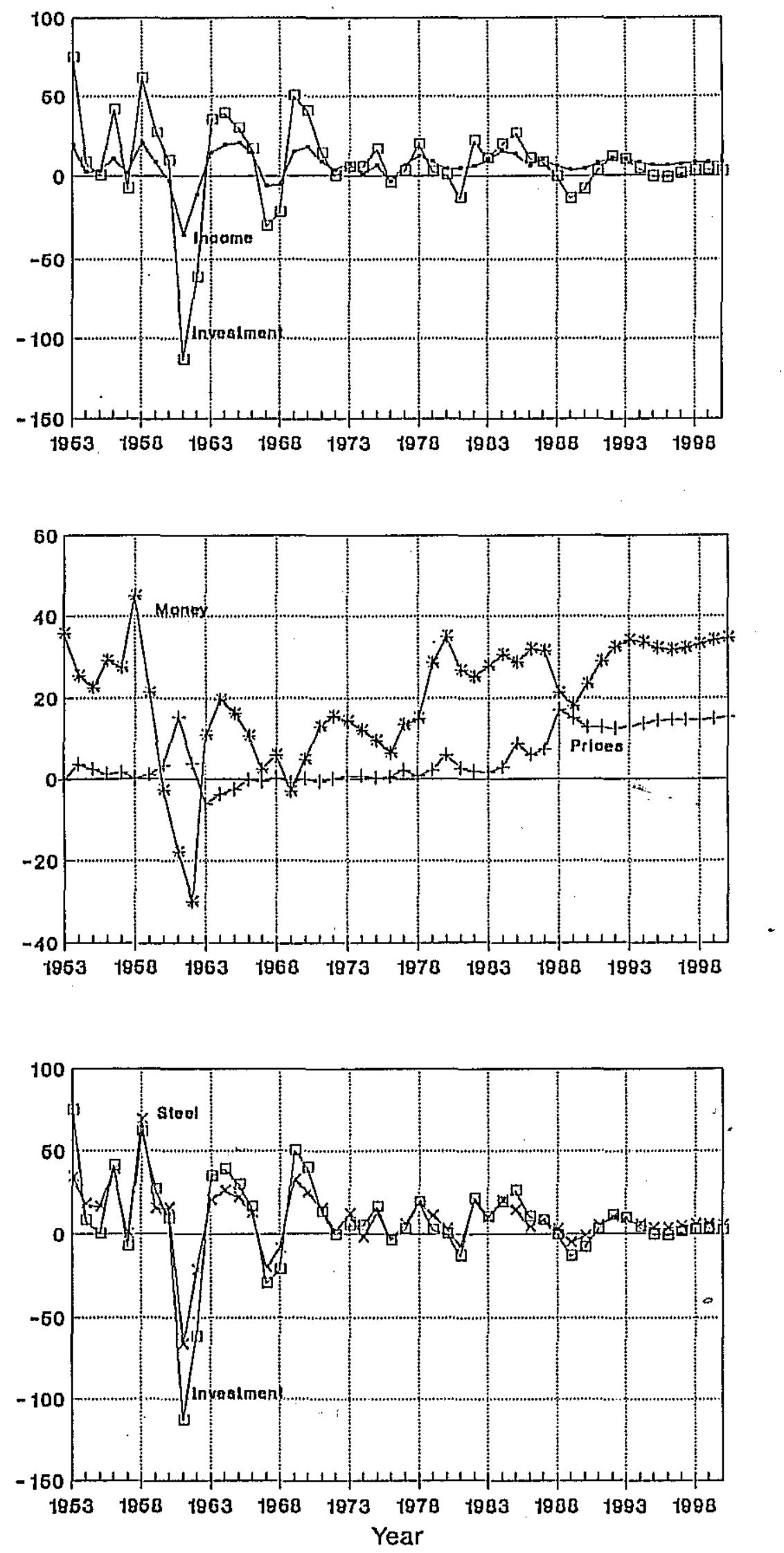

Fig. 8-- Actual and forecast values, changes 

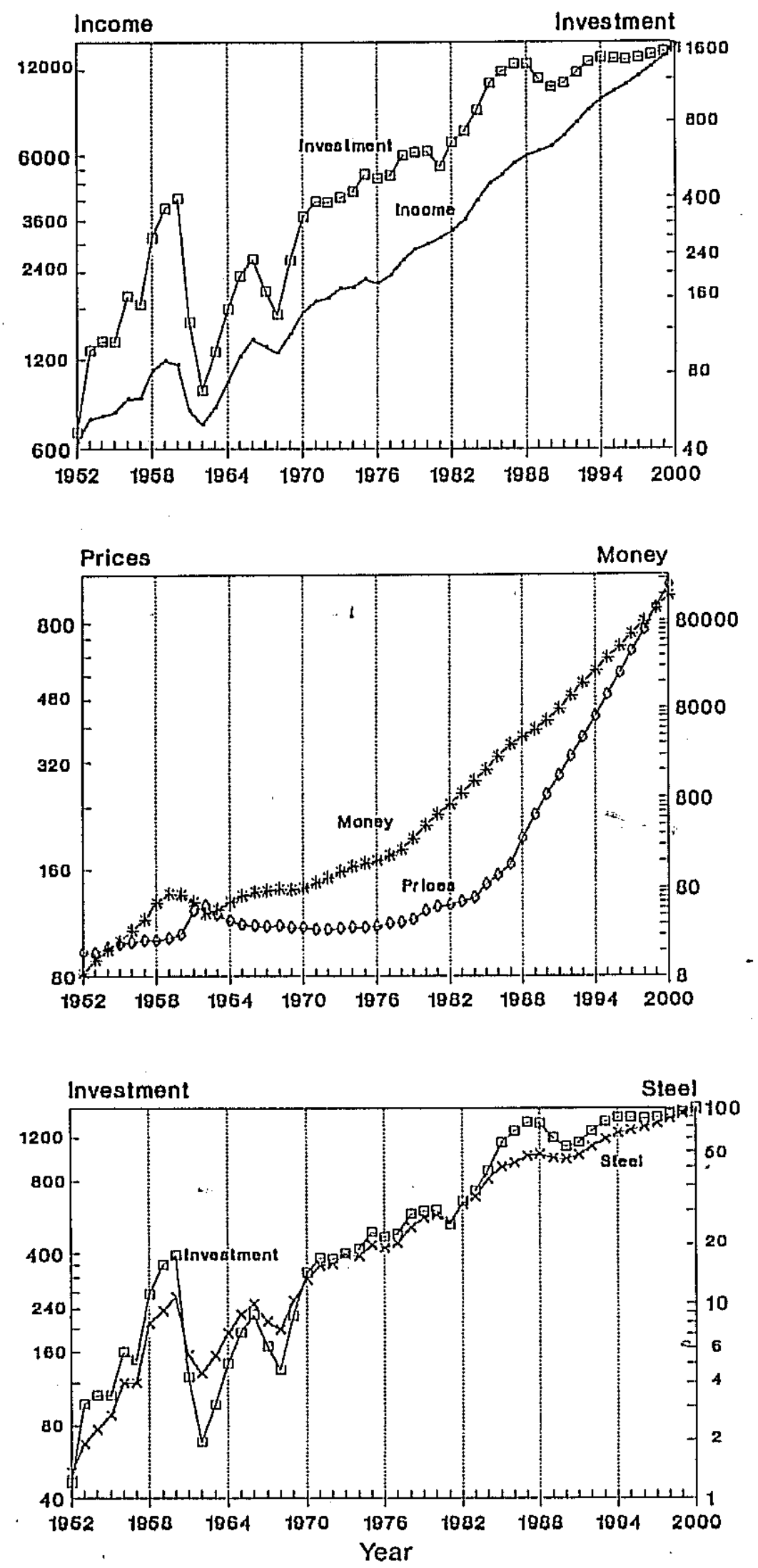

Fig. 9 -. Actual and forecast values, levels 


\section{Concluding Comments}

China has one of the largest steel markets in the world and, as in other developing countries, steel demand is growing. The purpose of this paper is to forecast Chinese steel consumption until the year 2000. The paper uses vector autoregressions because the market-oriented hypotheses that are used to build structural econometric models do not apply in a command economy. The moving average representation of the model is used to calculate variance decompositions and impulse responses that provide insights into the dynamic structure of the Chinese economy. An important advantage of VARs is that there is no need to specify exogenous variables over the forecast period.

Our model predicts that Chinese steel demand will grow from 60 milliqu tons in the late 80 s to close to 100 million tons by the year 2000. Currently, China is passing through a recession and steel consumption will stay below the? level of 1988 until 1992. After a strong recovery in 1992/93," steel demand, is predicted to grow at about five percent per annum in the second half of the 1990s. The variance decompositions and the impulse responses indicate that macroeconomic shocks account for most of the fluctuations in steel consumption. The Chinese economy is subject to strong real shocks that reflect political events and to price and monetary shocks that are policy induced. 


\section{Appendix 1}

\section{'The Data Source}

All data are from the 1989 Statistical Yearbook of China, except investment in 1952 which is from the 1985 release of the Year Book.

Steel demand is domestic steel consumption from 1953 to 1988 (pp. 374) and steel production for 1952 (pp. 299). Nominal income and nominal investment are from pages 29 and 48 , and their real series are derived by deflating by the price index. The Year Book quotes retail prices as ratios of the level in. a year divided by the level in the preceding year (pp. 689). These figureś were transformed into a continuous series of levels by setting 1956 equal to 100. The money stock is not available in the Year Book. Instead, we use savings account balances froll pp. 725 . 


\section{Appendix 2}

\section{Technical Details of the Model}

Let $y_{i t}$ be the log-change in the $i^{\text {th }}$ variable $(i=1, \ldots, 5)$ in year $t(t$ $=1, \ldots, 36)$. The $i^{\text {th }}$ equation of the model takes the form

$$
y_{i t}=a_{i}+\sum_{j=1}^{5} \sum_{\tau=1}^{k} \beta_{i j \tau} y_{j, t-\tau}+\epsilon_{i t},
$$

where $\alpha_{i}$ and the $\beta_{i j \tau}{ }^{\prime} s$ are coefficients to be estimated; $k$ is the lag length; and $\epsilon_{i t}$ is a white-noise disturbance term.

Following Litterman (1979), we use prior distributions for all the coefficients of the lagged variables in equation (A2.1). These are specified as independent normal distributions with following moments

$$
\left\{\begin{array}{c}
\mathbb{E}\left(\beta_{i j \tau}\right)= \begin{cases}1 & i=j, \tau=1 \\
0 & \text { otherwise }\end{cases} \\
V\left(\beta_{i j \tau}\right)=\left[\gamma f(\tau) \frac{g(i, j)}{s_{j} / s_{i}}\right]^{2},
\end{array}\right.
$$

where $\gamma$ is the overall tightness parameter; $f(\tau)$ is a lag decay function which shows how the lag coefficients decrease with increasing lags, $f(1)=1$; $g(i, j)$ measures the tightness of the prior on the coefficient of variable $j$ in the $i^{\text {th }}$ equation relative to the coefficient of variable $i$ and is defined as

$$
g(i, j)= \begin{cases}1.0 & i=j \\ 0.5 & i \neq j\end{cases}
$$


and $s_{i}$ is the standard error of a univariate autoregression for variable $i$. As $f(1)=g(i, i)=1$, the quantity $\gamma s_{i} / s_{j}$ is interpreted as the standard deviation of the prior on the first own-lag coefficient. We set $\gamma=.67$. The function $f(\tau)$. measures the tightness of the prior on lag $\tau$ relative to lag 1 . We use $f(\tau)=.58^{\tau-1}$. The use of $s_{i}$ and $s_{j}$ in (A2.2) corrects for different magnitudes of variables $i$ and $j$.

The method of mixed estimation (Theil, 1971, pp. 347-52) can be applied to $(\Lambda 2.1)$ and $(\Lambda 2.2)$ for $i, j=1, \ldots, 5$. We choose $k=4$ lags on the basis of eliminating as much as possible of the serial correlation in the residuals. 


\section{References}

Canavan, P.D. (1983). The Determination of Intensity of Use: 1 Case Study of Tin Solder End Uses. Ph.D. thesis, Pennsylvania State University.

Castro, S.Z. (1988). "Changing Trends in World Metal Demand: The Case of Tin", Natural Resources Forin! 12: 149-58.

Findlay, C. and Xin, L. (1985). "China's Iron and Steel Industry Policy: Implications for Australia", Pacific Economic Papers No. 127, Australia-Japan Research Centre, Canberra: Australian National University.

Labys, W.C., F.R. Field and J. Clark (1985). "Mineral Models". In W.A. Vogely (ed) The Economics of the Mineral Industries, New York: American Institute of Mining, Metallurgical and Petroleum Engineers, pp. 337-79.

Litterman, R.B. (1979). "Techniques of Forecasting Using Vector Autoregressions". Horking Paper No 115, The Federal Reserve Bank of Minneapolis.

Malenbaum, W. (1973). Material Recuirements in the United States äind Abroad in the Year 2000. Philadelphia: University of Pennsylvania Press.

(1975). "The Law of Deilland for Minerals". Proceedings of the Council of Economics, 104th Annual Meeting of the American Institute of Mining, Metallurgical and Petroleum Engineers, pp. $147-55$.

Roberts, M.C. (1985). Theory and Practice of the Intensity of Use Method of Mineral Consumption Forecasting. Ph.D. thesis, University of Arizona. 
Roberts, M.C. (1990). "Predicting Metal Consumption: The Case of US Stee1". Resources Policy 16: 56-73.

Thei1, II. (1971). Principles of Econometrics. New York: John Wiley and Sons.

Tilton, J.E. (1986). Beyond Intensity of Use". Materials and Society 10: 245- 50 .

(1989a). "Changing Trends in Metal Demand and the Decline of Mining and Mineral Processing in North America". Resources Policy 15: 12-23.

(1989b). "The New View of Minerals and Economic Growtl". Economic Record 65: 265-78.

Wagenhals, G. (1983). A Bibliography of Econometric Non-Ferrons Metal. Market Mode1s. Heidelberg: Alfred Weber Institute, University of lleidelberg.

(1984). "Econometric Models of Minerals Markets: Uses and Limitations". Natural Resources Forum 8: 77-86.

Zhang Xiao-qin (1988). "Forecasting Steel Demand in China in 2000: Implications for China's Iron and Steel Industry." Paper prepared for the Second joint Seminar of ITRI, MOFFERT of China and the University of Adelaide.

Yong Gan Shen (1988). "Forecasting China's Steel Products Demand." Mimeo. 